日本人類遺伝学会第 28 回大会記事 (1983)

\title{
Proceedings of the 28th Annual Meeting of the Japan Society of Human Genetics, 1983
}

\author{
会場 宝塚市梅野 1-46 宝家ホテル \\ 会期 昭和 58 年 11 月 9 日 11 日 \\ 大会会長 松本秀雄 (大阪医大教授) \\ 大会副会長 古山順一 (兵庫医大教授) \\ 発表 学会賞受賞講演

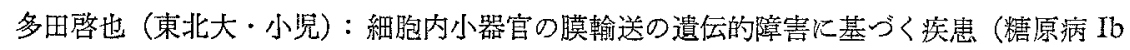 \\ 型)一新しい遺伝疾患カテゴリーの提唱.

\section{会長講演} \\ 松本秀雄（大阪医大・法医）：ヒト免疫グロブリンの遗伝標識に関する研究 \\ 特別講演 \\ 1) Jacques Constans (Centre d'Hemotypologie du CNRS, Toulouse, France): The Poly- \\ morphism and the Evolution of Vitamin D-Binding Protein \\ 2) Erna van Loghem (Red Cross Blood Transfusion Services, Amsterdam, The Nether- \\ lands): Genetic Markers of Human Immunoglobulins and Evolution

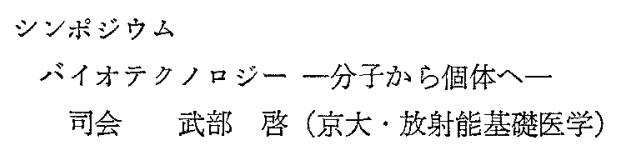

第 1 日 (11 月 9 日)

松本大会会長の開会の辞に引き続き，午前中に A, B 2 会場で一般講濱 32 題の発表が市った. 午後は 2 題の特別講演の後, 再び $\mathrm{A}, \mathrm{B}$ 会場で一般講演 36 題の発表があった.なな゙, 2 日間に わたる 28 題の永スター展示が開始された。

第 2 日 (11月 10 日)

午前中 2 会場で 34 題の一般講演があり, 引き続党記念撮影が行われた，个後は総会議事に引き 続いて学会賞授賞式, 同受賞講演が行われた。 その後, 会長講演があり, 引き続き C, D 2 会場で ポスターセッションが行われた。講演終了後, 懇親会が開かれた。

第 3 日 (11月 11 日)

午前中シンポジウムが行われ，午後は 2 会場で一般講演 30 題の発表がかった. その後, 古山大 会副会長の閉会の辞をもって, 全日程を終了した.

\section{理事会}

日 時: 昭和 58 年 11 月 8 日 $15: 00 \sim 17: 00$

場 所: 宝塚ホテル

出席者 : 井上会長, 岡島, 外村, 荻田各理事, 松本大会長, 古山大会副会長, 池内, 黑木各幹事

1. 編集関係では，投稿論文が增加しているが，大会号の編集方針を編集委員長に一任することで当 
分様子をみることになった。

2. 59 年度大会漼㑽状海が荻田次期大会長より報告され，ホスターセッションを重視する方針が示 された.

3. 60 年度大会開催地, 大会長の案が示され了承された.

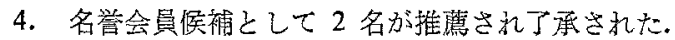

5. 新理重の前務分担の5ち未決定の IGF 担当は荻田理事に泆定された。

6. 新委員長, 新幹事が委嘱された。（評議員会の項汇記載）

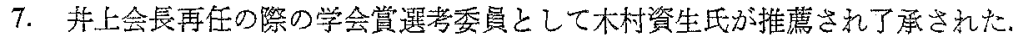

8. 新旧役員の交代時期について検討され，徉来の方針が再確認された。

9. 它の他, IGF 関俰, 名誉会長の化などが請議された.

\section{获議員会}

日 時: 昭和 58 年 11 月 8 日 $17: 00 \sim 19: 00$

場 所 : 宝塚ホテル

議事に先立ち，物故会負の御冥福を祈った。

I. 報告事項

1. 庶務瞃告

1）会員の異動状況，理事会開催（9月10日，11月8日）について報告がなされた。

2) 本年 6 月の評議員改選に伴って任期満丁して理事，学会賞選考委員の改選方行われ，岡島 道夫，外村 晶，荻田善一の 3 氏名新理事に，节上英二，外村 晶の 2 氏架新学会賞選考委

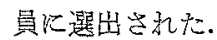

3）理猙業務分担が報告された。（9月10日，11月8日の理事会の項参照）

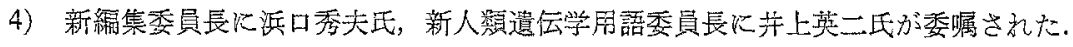

2. 会計報告

1) 昭和 57 年度会計報告晾よび同監叠報告がなされた。

2）昭和 58 年度会計中間報告があった。

3. 編集報告

論文の投稿，受理状沅等について報告きれた。

4. 昭和 59 年度大会準備状況報告（荻田善一次期大会長）第 29 回日本人類遺伝学会学，路和 59

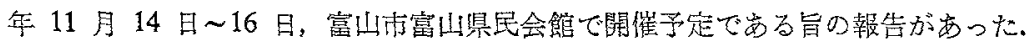

5. 委員会報告

1) 学会賞選考委員会

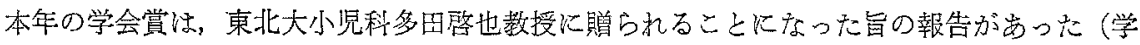
会記衰参照，人遺誌 28 巻 2 号 193 面).

2) 人類遗伝学会用語委員会

用語㚣員会新委員長には井上会長が選出された旨報告された，委員会設立の経緯と用語集編 箘の進行状沉の報告肪めった。

6. 理事把当事項等報告

1）文部省科研費関係

從来科研費の电請は「医学一般」として报われていたが，昭和 59 年度より「人類遗伝学」 の継目が諗められた旨の報告があった。 
2）その他，学術会議関連，日本医学会評議員会の報告があった.

7. その他

国際ふたご学会の日本誘致, 日本国際賞, 関連学会協徎, 日本先天代謝異常学会の新設, 人類 学会の遺伝分科会等に関する報告があった。

II. 協議事項

1. 次期会長候補として，井上英二現会長が満場一致で推薦された。そ礼に伴い空席となる学会賞 選考委員に次点の木村資生評議員が選出された。

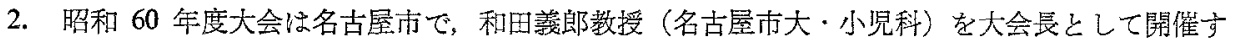
る案が示され了承された。

3. 名誉会員として北原経太氏（座罗島大名誉教授），西村秀雄氏（京大名誉教授）肪澫場一致で 推薦された。

4. 役員の選定に関する会則の一部改正が検討され，次のような改正案が示された。

第十一条「……評議員は各地区ごとに普通会員の互選による，……を「……各地区ごとに国 内在住の普通会員の……と改める.

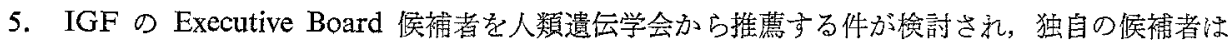
出さない方針が了承された。

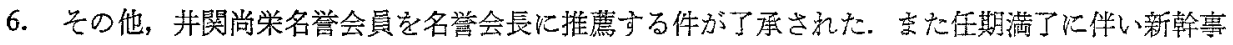
は次の如く委䃛する旨の報告が要った。

庶務：松并一郎，会計：西村泰治，蹁集：池内達郎

なお学術会議の発達障害研究連絡委員会の現況についての報告があった.

総会議事

I 、 報告㗆項

1. 庶務報告

会員の異動状況, 理事会の開催, 理事, 学会賞選考委員の選挙結果, 理事業務分担, 委員長委 嘱等についての報告がめった。

会員の異動状況

(57年12月31日現在)

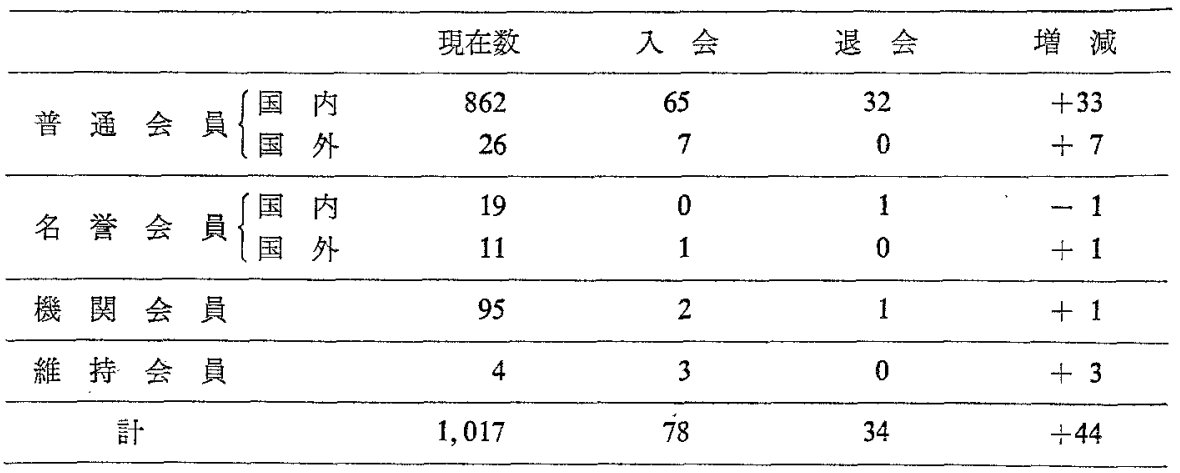

2. 会計報告

昭和 57 年度会計報告ならびに同監查報告がなされ，引き続いて昭和 58 年度会計中間報告が あった。

Vol. 29, No. 2, 1984 
昭和 57 年度会計報告

\begin{tabular}{|c|c|c|c|}
\hline 収 & 入 & & 出 \\
\hline 前年度繰越金 & $4,664,316$ 円 & 雑誌刊行費 & $5,133,931$ 円 $\left\{\begin{array}{l}26 \text { 覜 } 1 \cdot 2 \text { 号 } \\
2 \sim 3\end{array}\right\}$ \\
\hline 費 & $4,545,450$ & 雉誌発送費 & 410,477 \\
\hline 雑誌売上代 & 562,020 & 嚾誌編集費 & 45,800 \\
\hline 諭文揭載料 & 340,499 & 事 務 費 & 536,957 \\
\hline 文部省科研費 & $1,280,000$ & 理事会旅費 & 97,900 \\
\hline 医師会助成金 & 100,000 & 人件 費 & 480,000 \\
\hline 広告揭載料 & 95,000 & 次年度繰越金 & $4,932,241$ \\
\hline 預 金 利子 & 50,021 & & \\
\hline \multirow[t]{2}{*}{ 計 } & $11,637,306$ 円 & 計 & $11,637,306$ 円 \\
\hline & \multicolumn{2}{|c|}{ 昭和58年度中間報告 } & （58年1月1日～10五25日） \\
\hline 収 & 入 & & 出 \\
\hline 前年度繰越金 & 4,932,241円 & 雄誌刊行費 & 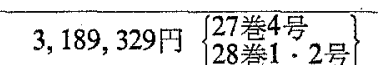 \\
\hline 会費 & $4,988,449$ & 雑誌発送費 & 224,553 \\
\hline 雜誌志上代 & 697,850 & 雑誌編集費 & 20,000 \\
\hline 論文揭载料 & 371,471 & 事 務 費 & $1,261,475$ \\
\hline 文部省科研穓 & $(1,310,000)$ & 理事会旅費 & 167,400 \\
\hline 医師会助成金 & 200,000 & 人 件 費 & 300,000 \\
\hline 広告揭載料 & 280,000 & & \\
\hline 預 金 利子 & 48,939 & & \\
\hline 計 & $12,828,950$ 円 & 計 & $5,162,757$ 円 \\
\hline
\end{tabular}

3. 編集報告

論文の投稿，受理状況等についての報告があった。

4. 昭和 59 年度大会準備状沅について荻田次期大会長からの報告が㘯った。

5. 委員会報告

学会賞選考委員会，人類遺伝学用語委員会より，それぞれ報告がなされた(評議員会記録参照).

6. 理事担当事項等報告

文部省科研費関係，学術会議関連，日医評議員会，学術会議発達障邫研連等についての報告が なさ机だ。

7.その他，国際ふたご学会，日本国際賞，学会協賛等に関する報告があった。

II. 協議事項

1. 次期会長候補として評議員会より井上英二現会長が推薦され。満場一致で次期会長に決定した。 それ伴い空席となる学会賞選考委員汇は木村資生評議員が推萀され了承された。 な物，新幹事の委啒乃報告された。

2. 昭和 60 年度大会開催地，大会長案が示され，満場一致て了承された (評議員会記録参照).

3. 北原経太，西村唀雄の雨氏を厹れぞれ 41 人目，42 人目の名誉会員以，井関尚栄名誉会員を名 誉会長に推萀することが提案され満場一致で了承された。

4. その他，IGF Executive Board の推薦，会則一部改正，名誉会長の件等が討議された。 (1981-1983 年度庶務幹事 黑木良和) 